\title{
ISOLATION AND CHARACTERIZATION OF MITOCHONDRIAL DNA FROM THE ENDANGERED WHITE-CLAWED CRAYFISH AUSTROPOTAMOBIUS PALLIPES PALLIPES, LEREBOULLET, 1858.
}

\author{
F. GRANDJEAN, C. SOUTY-GROSSET.
}

Laboratoire de Biologie Animale, URA CNRS n 1975, Université de Poitiers, 40 avenue du Recteur Pineau, 86022 Poitiers Cedex (France).

\begin{abstract}
Mitochondrial DNA (mtDNA) variation in the white-clawed crayfish, Austropotamobius pallipes pallipes, was examined by restriction endonuclease analysis of samples obtained from three geographical locations representing two very different habitats : the Crochatière and the Magot for brooks and the Pinail for ponds. This study used a new type of molecular marker in crayfish. The method of mtDNA extraction was not based on the clear lysate method or on ultracentrifugation and used no end-labelling detection. It is discussed according to the literature about marine crustaceans. MtDNA was digested with 6 endonucleases. The molecule size of the mtDNA of the white-clawed crayfish was approximately $17750 \pm 580$ base pairs. Two restriction enzymes produced polymorphic digestion patterns, defining a total of three haplotypes (1-3). There was a shared haplotype 2 between individuals among the two brooks. The haplotype 3 was only found in individuals obtained from ponds of Pinail.
\end{abstract}

Key-words : Austropotamobius pallipes, mtDNA, genetic variation, RFLP.

\section{ISOLATION ET CARACTÉRISATION DE L'ADN MITOCHONDRIAL CHEZ L'ÉCREVISSE À PATTES BLANCHES AUSTROPOTAMOBIUS PALLIPES PALLIPES, LEREBOULLET, 1858, ESPÈCE MENACÉE.}

\section{RÉSUMÉ}

La variabilité de l'ADN mitochondrial (ADNmt) chez l'écrevisse à pattes blanches, Austropotamobius pallipes pallipes, est examinée par l'utilisation d'endonucléases de restriction à partir d'échantillons issus de trois sites caractérisant deux types d'habitats : la Crochatière et le Magot pour les ruisseaux et le Pinail pour les mares. Cette étude met en oeuvre un nouveau type de marqueur moléculaire chez les écrevisses. La méthode d'extraction de l'ADNmt n'est pas basée sur la méthode de lyse alcaline ou sur des ultracentrifugations et n'utilise pas de marquage terminal. La technique d'extraction est discutée par rapport aux méthodes employées chez les crustacés marins. L'ADNmt est digéré à l'aide de six endonucléases. La taille de la molécule d'ADNmt chez l'écrevisse à pattes blanches est approximativement de $17750 \pm 580$ paires de base. Deux enzymes de restriction donnent des profils de restriction polymorphes, définissant trois haplotypes (1-3). L'haplotype 2 est présent dans les populations provenant des deux ruisseaux. L'haplotype 3 est exclusivement trouvé chez les écrevisses provenant des mares du Pinail.

Mots-clés : Austropotamobius pallipes, ADNmt, variabilité génétique, PLFR. 


\section{INTRODUCTION}

The natural distribution of Austropotamobius pallipes pallipes (Lereboullet, 1858) covers Western Europe from $56^{\circ} \mathrm{N}$ in Great Britain south to $38^{\circ} \mathrm{S}$ in Spain and from $8^{\circ} \mathrm{W}$ in Ireland to $16^{\circ} \mathrm{E}$ in former Yugoslavia. During the last century, native populations of $A$. pallipes throughout Europe and in particular in France (VIGNEUX et al., 1993) have been greatly reduced in number. This decline is due to acidification of rivers, pollution, exotic crayfish acclimatization, and other human interference with natural habitats (WESTMAN, 1985). It has recently been classified by the I.U.C.N. as being vulnerable and rare (GROOMBRIDGE, 1994).

If the conservation of this species required the preservation of existing populations, it must also include restocking operations in suitable habitats. Before restocking and stocking, it is imperative to know genetic differences between populations, because local populations may be adapted to their local environment and introduction of genetically different individuals could adversely alter the gene pool.

Few studies have been performed to appreciate the level of morphometric variation in A. pallipes. ALBRECHT (1982) found morphological differences in a number of characters between populations sampled from different regions of Europe. ATTARD and VIANET (1985) showed morphological differences between French, Irish and Italian populations. However, electrophoretic analysis of general proteins did not reveal any differences within the species (NEMETH and TRACEY, 1979 ; ALBRECHT and VON HAGEN, 1981 ; AGERBERG, 1990). ATTARD and VIANET (1985) revealed a low level of heterozygosity ranging from 0.013 to 0.026 between populations. In general, very little is known about populations genetics in crayfish. At the present time, only electrophoretic analysis has been performed and this method seems not to be appropriate for the study of intraspecific genetic variation whatever the crayfish species (BROWN, 1980 ; BUSACK, 1988 ; FEVOLDEN and HESSEN, 1989). This lack of applied genetic research is harmful from a conservation (as well as stock management) point of view.

In the last decade, another method of investigating genetic relationships has been developed from the analysis of mitochondrial DNA (mtDNA) using analysis of Restriction Fragment Length Polymorphism (R. F. L. P.). The mtDNA has several characteristics which make it useful as a species-specific marker. The usually maternal and non-recombinational transmission and the faster rate of evolution of mtDNA, compared with nuclear genome (5 to 10 times more rapid) (BROWN et al., 1979), make it useful for the study of phylogenetic relationships or of microevolutionary processes within species (WILSON et al., 1985 ; AVISE et al., 1987 ; MORITZ et al., 1987). Generally, genetic variation among populations is often more dramatic for mtDNA than for nuclear DNA or nuclear gene products, such as isozymes (AVISE, 1985 ; ZWANENBURG et al., 1992). The scarcity of papers on crustaceans, indeed even none on crayfish, is probably related to the difficulty of extracting total mtDNA for RFLP analysis. A few studies have been performed on marine Decapods. KOMM et al. (1982) showed preliminary results in Panulirus argus and revealed some heterogeneity between individuals. In Jasus verreauxi, BRASHER et al. (1992a) studied 25 individuals with six restriction enzymes : two restriction sites (on 45 obtained) were sufficient to distinguish New Zealand populations from Australian ones. In Jasus edwardsii, OVENDEN et al. (1992) have compared 13 populations and obtained a nucleotides substitution mean of about 0.78 whereas the heterozygosity was low in this same species $(0.015$ according to SMITH et al., 1980). BRASHER et al. (1992b) confirmed a high level of mitochondrial polymorphism in the genus Jasus by studying 5 species. Seeing that OVENDEN (1990) specified that some marine species have less variable mitochondrial genomes than previously studied terrestrial and freshwater species, we can hope that mitochondrial DNA will be a suitable molecular marker in crayfish.

The objectives of this study were twofold: firstly, to outline a new molecular technique for studying genetic variability of mitochondrial DNA in crayfish and, secondly, to appreciate the level of genetic variability within and between natural populations of $A$. pallipes. 


\section{MATERIALS AND METHODS}

Adult crayfishes were collected from two streams situated in the region of PoitouCharentes (France) : the Crochatière, the Magot and from a pond : the Pinail. 20 animals from each brook were used for genetic study, but only 5 animals of Pinail have been analysed because this population seems to be relic. Heart, green glands and testes obtained from fresh animals were used for the mtDNA extraction.

Each sample was homogenized in a Potter-Elvehjem homogenizer with a glass/teflon pestle after adding $15 \mathrm{ml}$ of sucrose-TE-buffer $(0.25 \mathrm{M}$ sucrose, $60 \mathrm{mM}$ EDTA, $30 \mathrm{mM}$ Tris- $\mathrm{HCl}$ and $1.5 \% \mathrm{NaCl}, \mathrm{pH} 8$ ). The homogenate was centrifuged in a $15 \mathrm{ml}$ centrifuge tube at $700 \mathrm{~g}$ for $20 \mathrm{~min}$ at $4^{\circ} \mathrm{C}$ to pellet nuclei and cellular debris. The supernatant, containing the mitochondria, was transferred to a second tube and centrifuged again under the same conditions. The remaining supernatant was centrifuged at $20000 \mathrm{~g}$ for $20 \mathrm{~min}$ at $4^{\circ} \mathrm{C}$ and a first crude mitochondrial pellet was obtained. To purify the first resulting mitochondrial pellet, it was resuspended in $15 \mathrm{ml}$ of TE-buffer (60 mM EDTA, $30 \mathrm{mM}$ Tris- $\mathrm{HCl}$ and $1.5 \% \mathrm{NaCl}, \mathrm{pH} 8$ ) and spun again under the previous conditions. The pellet containing the mitochondria was resuspended in $980 \mu \mathrm{l}$ of TE-buffer and $20 \mu \mathrm{l}$ of $20 \%$ Nonidet P-40 (Sigma) was added (final concentration of $0.4 \%$ ) on ice during $10 \mathrm{~min}$ with the aim of disrupting the mitochondrial membranes. The tubes were centrifuged for $10 \mathrm{~min}$ at $12800 \mathrm{~g}$ to $4^{\circ} \mathrm{C}$. The supernatant was phenol-extracted twice by adding an equal volume of saturated phenol $(\mathrm{pH} 8)$ to eliminate the proteins in the sample. After each extraction, the sample was spun for $8 \mathrm{~min}$ at $12000 \mathrm{~g}$ to separate the aqueous and phenol phases. Residual phenol was removed by a single chloroform - isoamyl extraction. Sodium acetate $(\mathrm{pH}$ 6) was added to a final concentration of $0.3 \mathrm{M}$ and the mtDNA precipitated by addition of one volume of $100 \%$ isopropanol followed by standing for 1 hour at $-20^{\circ} \mathrm{C}$. The mtDNA was pelleted at $15000 \mathrm{~g}$ for $30 \mathrm{~min}$ to $4^{\circ} \mathrm{C}$ in an Eppendorf centrifuge and washed in $70 \%(\mathrm{~V} / \mathrm{v})$ ethanol. The sample was dried under vacuum for $45 \mathrm{~min}$ and dissolved in $40 \mu \mathrm{H} 2 \mathrm{O}$ for ovaries, $20 \mu \mathrm{l}$ for green gland and $10 \mu \mathrm{l}$ for heart.

Among the six enzymes used for the mtDNA analysis, five restriction endonucleases cut 6-base pairs : Pst I, Xho I, Bam HI, Eco RI and Hind III, and one cut 4-base pairs : Hpa II. The restriction fragments obtained were separated in $1.2 \%$ agarose gels in TE-buffer for $15 \mathrm{~h}$ at 30 volts. Gels were stained with ethidium bromide and visualized with a UV light transilluminator. The restriction fragment patterns from each of the six endonucleases were identified by a letter, each individual being characterized by a composite haplotype of several letters.

\section{RESULTS}

The size of the mitochondrial genome was estimated by summing the restriction fragment sizes obtained after digestion with the following enzymes Pst I, Eco RI, Xho I (table I). The size of the mtDNA of the white-clawed crayfish was found to be approximately $17750 \pm 580$ base pairs.

Hind III and Hpa II produced the greatest number of bands, many of small size. As the sums of these lengths are comparatively low, it is likely that even smaller fragments were undetected by the coloration method. For tested enzymes Pst I, Bam HI, Eco RI, no difference in the restriction pattern between individuals could be detected (table I). Bam $\mathrm{HI}$ had no restriction site in the molecule.

Two patterns were observed for the enzymes Hpa II and Hind III (table I and figure 1). For these enzymes, different morphs were separated by a single loss or gain of a restriction site. In total, three different composite genotypes (haplotypes) were detected among the 45 crayfishes representing the three populations (table II).

No intraspecific variability of the mitochondrial genome was apparent in Magot and in Pinail, all crayfishes exhibited patterns 2 and 3, respectively. The haplotype 3 was only found in Pinail. The population of Crochatière showed an intraspecific variability by using the restriction enzyme Hind III. The haplotype 1 was more frequent in this population than haplotype 2, with respectively $75 \%$ and $25 \%$. 
Table I : Estimated sizes (in base pairs) of mtDNA fragments resulting from digestion with restriction endonucleases in $A$. pallipes. For each enzyme, letters refer to the different genotypes revealed.

Tableau I : Tailles estimées (en paires de base) des fragments de restriction obtenus après digestion de l'ADNmt d'A. pallipes par différentes enzymes de restriction. Pour chaque enzyme, les lettres correspondent aux différents types de profils de restriction observés.

\begin{tabular}{|c|c|c|c|c|c|c|c|}
\hline & \multicolumn{2}{|c|}{ Hind III } & \multicolumn{2}{|c|}{ Hpa II } & \multirow{2}{*}{$\begin{array}{c}\text { Pst I } \\
\text { A }\end{array}$} & \multirow{2}{*}{$\begin{array}{c}\text { Xho I } \\
\text { A }\end{array}$} & \multirow{2}{*}{$\frac{\text { Eco } R}{A}$} \\
\hline & A & B & A & B & & & \\
\hline & 5520 & 5520 & 4330 & 4330 & 8235 & $9200 \times 2$ & 13545 \\
\hline & 2710 & 1590 & 1730 & 1460 & 7460 & & 1865 \\
\hline & 1425 & 1425 & 1460 & $1250 \times 2$ & $935 \times 2$ & & $935 \times 2$ \\
\hline & 1050 & 1130 & 1250 & $1160 \times 2$ & & & \\
\hline & 935 & 1050 & $1160 \times 2$ & 950 & & & \\
\hline & 845 & 935 & 950 & 630 & & & \\
\hline & 615 & 845 & 885 & 560 & & & \\
\hline & 530 & 615 & 630 & & & & \\
\hline & & 530 & 560 & & & & \\
\hline Total & 13630 & 13640 & 11280 & 10455 & 17565 & 18400 & 17280 \\
\hline
\end{tabular}

Table II : Three enzyme haplotypes of A. pallipes. The letter designations refer to single enzyme genotype in the order presented in table I. (Bam HI does not cut the mtDNA).

Tableau II : Composition des trois haplotypes obtenus chez A. pallipes. L'ordre des lettres correspond à celui présenté dans le tableau I. (Bam HI ne coupe pas l'ADNmt).

\begin{tabular}{ccc}
\hline Location & Type & Haplotype \\
\hline Crochatière & 1 & AAAAA \\
Crochatière / Magot & 2 & BAAAA \\
Pinail & 3 & ABAAA \\
\hline
\end{tabular}




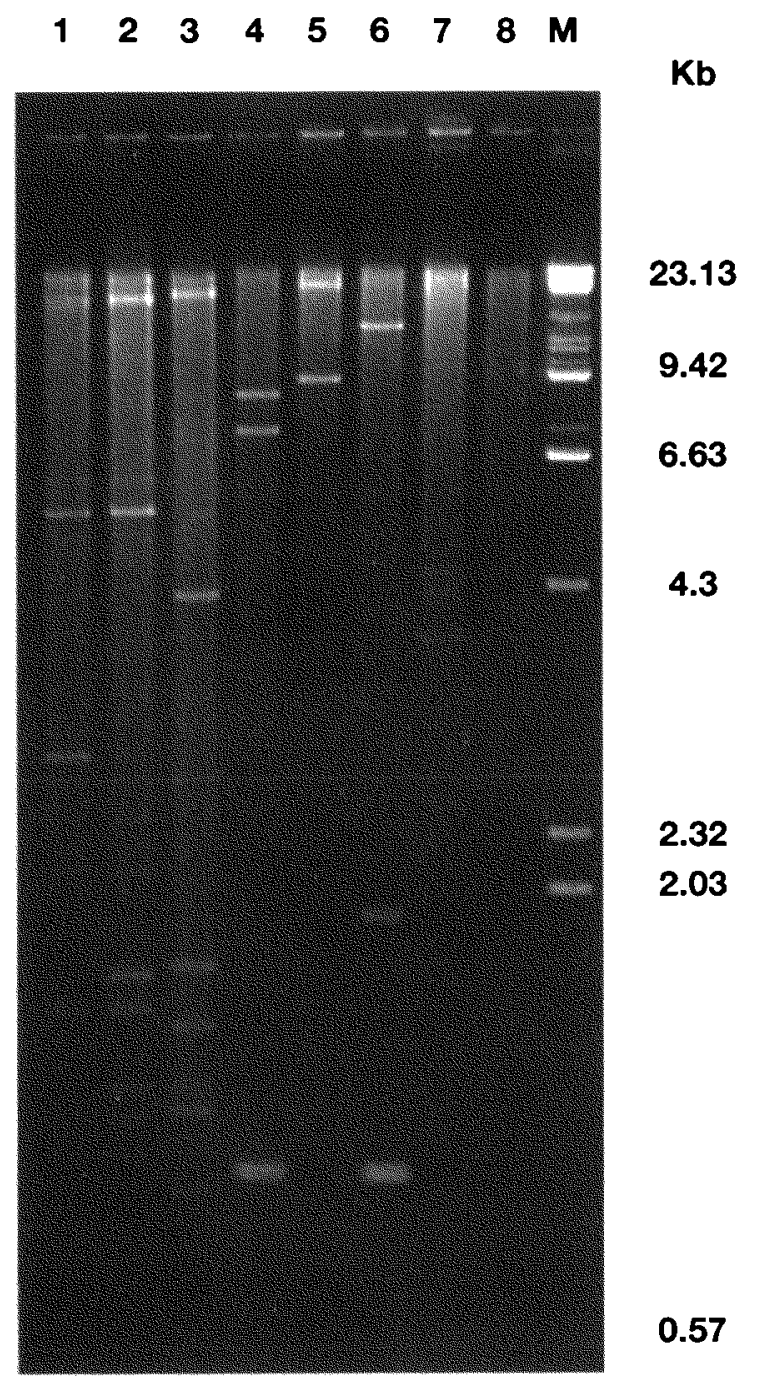

Figure 1 : Example of ethidium bromide coloration stained agarose gel of mtDNA digestion patterns of $A$. pallipes. On the right side, are given fragment sizes in Kilobase pairs (Kb) of Lambda-phage DNA digested by Hind III. Lanes : 1-2 = Hind III (patterns A and B, respectively), 3 = Hpa II (pattern A), 4 = Pst I, 5 = Xho I, $6=$ Eco RI, 7-8 = Bam HI, M = size standard.

Figure 1 : Exemple d'un gel coloré au bromure d'éthidium montrant des profils de restriction obtenus après digestion enzymatique de l'ADNmt d' $A$. pallipes. Sur la droite sont indiquées les tailles des fragments (kb) obtenus après digestion par Hind III du marqueur de référence (ADN du phage Lambda). Lignes 1-2: Hind III (profils $A$ et $B$ respectivement) ; 3 : Hpa II (profil A) ; 4 : Pst I ; 5 : Xho I ; 6 : Eco RI ; 7-8 : Bam HI ; M : marqueur de taille.

\section{DISCUSSION}

Up to date, no study has been carried out concerning mtDNA diagnostic marker in population genetics of freshwater crayfish. The establishment of a reliable mtDNA extraction method in crayfish was indeed an essential and difficult step of our work. Papers, essentially performed on marine crustaceans, related very time-consuming methods giving low yields of extraction ; in Panulirus argus, KOMM et al. (1982) obtained only three restriction profiles using radiolabelled detection from mtDNA extracted by a cesium chloride gradient. In our laboratory, 
we have developed a rapid extraction method for Penaeus japonicus mtDNA, more suitable to population genetics studies and which corresponded to a modified version of alkaline lysis commonly employed to extract plasmids (BOUCHON et al., 1994). Unfortunately, the method is too drastic if it is applied to freshwater crayfish. We proposed here another rapid method of extraction of mtDNA especially adapted in crayfish. The method involved using an adapted extraction buffer (concentration of EDTA is relatively high compared to other buffers used in crustaceans) and a specific lysis of mitochondrial membranes by NonidetP40. The use of this detergent was essentially made for use with molluscs (see BLOT et al., 1990, in mussels and MURRAY et al., 1991, in Partula) and in the crustacean Jasus (BRASHER et al., 1992b), but its concentration was higher (from 1 to $2 \%$ ). Our method has permitted the use of six restriction enzymes without the radiolabelled method as used by KOMM et al. (1982), Mc LEAN et al. (1983), SILBERMAN et al. (1994).

The preliminary results presented here have permitted, firstly, the characterization of the size of mtDNA in A. pallipes ( $17750 \pm 580 \mathrm{bp})$ and, secondly, to reveal a genetic variability between three populations. The size of the mitochondrial genome in $A$. pallipes was that generally found in animals and more particulary in Crustacea Decapoda (BOUCHON et al., 1994). In France, generally, $A$. pallipes is found in the same habitat that trout prefer (running water, rich in calcium and dissolved oxygen, with refuges) (LACHAT and LAURENT, 1987) as in the Crochatière and in the Magot. However, in the Pinail, $A$. pallipes was found in very small ponds (100 m2) with physical and chemical conditions very particular for this species. Physical and chemical measurements, carried out this year in these ponds, have revealed very low rates of dissolved oxygen and calcium with temperatures up to $29^{\circ} \mathrm{C}$. In several freshwater decapods, the discontinuous nature of habitats between populations was a source of genetic divergence (HEDGECOCK et al., 1976 ; FULLER and LESTER, 1980 ; AUSTIN, 1986 ; FEVOLDEN and HESSEN, 1989) although some others have shown low inter-populations divergence (BUSACK, 1989 ; HORWITZ et al., 1990). In our case, the low number of sampled animals in this population do not allow us to judge if this genetic differentiation was due either to a difference in the nature of habitat or to the founder effect.

This study has revealed an intrapopulational genetic variability within the Crochatière. However, the two haplotypes were very similar and only differ from one another by a gain or loss of one restrictions site. The lack of genetic variation in Pinail and Magot could be explained by several means. BARTON and CHARLESWORTH (1984) have showed that, at the population level, natural levels of mtDNA diversity may be drastically reduced by either strong selection pressures or a reduction in population size. AVISE et al. (1988) showed that intrapopulational mtDNA diversities are directly proportional to effective sizes of females. In Pinail, it seems that the nature of the habitat limited the population size (small surface, lack of hides, presence of several predators). The impact of the founder effect could be as important as selective pressures. However, the low number of animals taken for this analysis from the Pinail and the low number of restriction enzymes tested could explain this lack of genetic variation in populations of whiteclawed crayfish. According to O'CONNELL et al. (1995), a sample of 25-30 individuals is needed for investigating mtDNA diversity in a population. In Pinail, only five crayfishes have been analysed.

A mtDNA analysis is in progress on a great number of populations from Poitou-Charentes and will give or not a confirmation of the low levels of genetic variability of $A$. pallipes populations on a regional scale.

\section{ACKNOWLEDGEMENTS}

We would like to thank M. BRAMARD, member of the délégation régionale du Conseil Supérieur de la Pêche du Poitou-Charentes (C.S.P.), for field assistance during fishing operations. This work was supported by financial support from C.S.P. 


\section{REFERENCES}

AGERBERG A., 1990. Genetic variation in three species of freshwater crayfish, Astacus astacus L., Astacus leptodactylus Aesch. and Pacifastacus leniusculus (Dana), revealed by isozyme electrophoresis. Hereditas, 113, 101-108.

ALBRECHT H., 1982. Das System der europäischen Flusskrebse (Decapoda, Astacidae) : Vorschlag und Begrundung. Mitt. Hamb. Zool. Mus. Inst., 79, 187-210.

ALBRECHT H., VON HAGEN H.O., 1981. Differential weighting of electrophoretic data in crayfish and fiddler crabs (Decapoda : Astacidae and Ocypodidae). Comp. Biochem. Physiol., 70B, 393-399.

ATTARD J., VIANET R., 1985. Variabilité génétique et morphologique de cinq populations de l'écrevisse européenne Austropotamobius pallipes (Lereboullet, 1858) (Crustacea, Decapoda). Can. J. Zool., 63, 2933-2939.

AUSTIN C.M., 1986. Electrophoretic and morphological systematic studies of the genus Cherax (Decapoda : Parastacidae) in Australia. Ph.D. Thesis, University of Western Australia.

AVISE J.C., 1985. Identification and interpretation of mitochondrial DNA stocks in marine species. In H.E. Kumpf, R.N. Vaught, C.B. Grimes, A.G. Johnson and E.L. Naakamura, Eds, Proceedings of Stock Identification Workshop, 105-136.

AVISE J.C., ARNOLD J., BALL R.M., BERMINGHAM E., LAMB T., NEIGEL J.E., REEB C.A., SAUNDERS N.C., 1987. Intraspecific phyleogeography : the mitochondrial DNA bridge between population genetics and systematics. Annu. Rev. Ecol. Syst., 18, 489-522.

AVISE J.C., BALL R.M., ARNOLD J., 1988. Current versus historical population sizes in vertebrate species with high gene flow : a comparison based on mitochondrial DNA lineages and inbreeding theory for neutral mutations. Mol. Biol. Evol., 5, 331-344.

BARTON N.H., CHARLESWORTH B., 1984. Genetic revolutions, founder effects and speciation. Annu. Rev. Ecol. Syst., 15, 133-164.

BLOT M., LEGENDRE B., ALBERT P., 1990. Restriction fragment length polymorphism of mitochondrial DNA in subantarctic mussels. J. Exp. Mar. Biol. Ecol., 141, 79-86.

BOUCHON D., SOUTY-GROSSET C., RAIMOND R., 1994. Mitochondrial DNA variation and markers of species identity in two penaeid shrimp species : Penaeus monodon Fabricius and $P$. japonicus Bate. Aquaculture, 127, 131-144.

BRASHER D.J., OVENDEN J.R., BOOTH J.D., WHITE R.W.G., 1992a. Genetic subdivision of Australian and New Zealand populations of Jasus verreauxi (Decapoda : Palinuridae)preliminary evidence from the mitochondrial genome. New Zealand J. Mar. Freshwater Res., 26, 53-58.

BRASHER D.J., OVENDEN J.R., WHITE R.W.G., 1992b. Mitochondrial DNA variation and phylogenetic relationships of Jasus spp. J. Zool. Lond., 227, 1-16.

BROWN K., 1980. Low genetic variability and high similarities in the crayfish genera Cambarus and Procambarus. Am. Midl. Nat., 105, 225-232.

BROWN W.M., GEORGE M., WILSON A.C., 1979. Rapid evolution of animal mitochondrial DNA. Proc. Nat. Acad. Sci. USA., 1985, 76, 1967-1971.

BUSACK C.A., 1988. Electrophoretic variation in the red swamp (Procambarus clarki) and white river crayfish ( $P$. acutus) (Decapoda : Cambaridae). Aquaculture, 69, 211-226.

BUSACK C.A., 1989. Biochemical systematics of crayfishes of the genus Procambarus, subgenus Scapulicambarus (Decapoda : Cambaridae). J.N. Am. Benthol. Soc., 8 , 180-186.

FEVOLDEN S.E., HESSEN D.O., 1989. Morphological and genetic differences among recently founded populations of noble crayfish (Astacus astacus). Hereditas, 110, 149-158. 
FULLER B., LESTER L.J., 1980. Correlations of allozymic variation with habitat parameters using the grass shrimp, Palaemonetes pugio. Evolution, 34, 1099-1104.

GROOMBRIDGE B., 1994. I.U.C.N. Red list of threatened animals. $286 \mathrm{p}$.

HEDGECOCK D., SHLESER R.A., NELSON K., 1976. Applications of biochemical genetics to aquaculture. J. Fish. Res. Board Can., 33, 1108-1119.

HORWITZ P., ADAMS M., BAVERSTOCK P., 1990. Electrophoretic contributions to the systematics of the freshwater crayfish genus Engaeus Erichson (Decapoda : Parastacidae). Invert. Taxon, 4, 615-641.

KOMM B., MICHAELS A., TSOKOS J., LINTON J., 1982. Isolation and characterization of the mitochondrial DNA from the Florida spiny lobster, Panulirus argus. Comp. Biochem. Physiol., 73b, 923-929.

LACHAT G., LAURENT P.J., 1987. The habitats of Astacus astacus and Austropotamobius pallipes in the Morvan. Freshwater crayfish, 7, 61-68.

MCLEAN M., OKUBO C.K., TRACEY M.L., 1983. MtDNA heterogeneity in Panulirus argus. Experientia, 39, 536-538.

MORITZ C., DOWLING T.E., BROWN W.M., 1987. Evolution of animal mitochondrial DNA : relevance for population biology and systematics. Ann. Rev. Ecol. Syst., 18, 269-292.

MURRAY J., STINE O.C., JOHNSON M.S., 1991. The evolution of mitochondrial DNA in Partula. Heredity, 66, 93-104.

NEMETH S.T., TRACEY M.L., 1979. Allozyme variability and relatedness in six crayfish species. Heredity, 70, 37-43.

O'CONNELL M., SKIBINSKI D.O.F., BEARDMORE J.A., 1995. Mitochondrial DNA and allozyme variation in atlantic salmon (salmo salar) populations in Wales. Can. J. Fish. Aquat. Sci., $52,171-178$.

OVENDEN J.R., 1990. Mitochondrial DNA and marine stock assessment : a review. Aust. J. Mar. Freshwater Res., 41, 835-853.

OVENDEN J.R., BRASHER D.J., WHITE R.W.G., 1992. Mitochondrial DNA analyses of the red rock lobster Jasus edwardsii supports an apparent absence of population subdivision throughout Australia. Mar. Biol., 112, 319-326.

SILBERMAN J.D., SARVER S.K., WALSH P.J., 1994. Mitochondrial DNA variation and population structure in the spiny lobster Panulirus argus. Mar. Biol., 120, 601-608.

SMITH P.J., McKOY J.L., MACHIN P.J., 1980. Genetic variation in the rock lobsters Jasus edwardsii and J. novaehollandiae. New Zealand J. Mar. Freshwater Res., 14, 55-63.

VIGNEUXE., KEITH P., NOEL P., 1993. Atlas préliminaire des Crustacés Décapodes d'eau douce de France. Coll. Patrimoines Naturels, vol. 14, S.F.F., B.I.M.M.-M.N.H.N., C.S.P., Min. Env., Paris, $55 \mathrm{p}$.

WESTMAN K., 1985. Effects of habitat modification on freshwater crayfish. In : Habitat modifications and Freshwater Fisheries, J.S. Alabaster ed., Butterworths, London, 245-255.

WILSON A.C., CANN R.L., CARR M.G., GYLLENSTEN U.B., HELM-BYCHOWSKI M., HIGUSHI R.G., PALUMBI S.R., PRAGER E.M., SAGE R.D., STONEKING M., 1985. Mitochondrial DNA and two perspectives on evolutionary genetics. Biol. J. Linn. Soc., 26, 375-400.

ZWANENBURG K.C.T., BENTZEN P., WRIGHT J.M., 1992. Mitochondrial DNA differentiation in western North Atlantic populations of Haddock (Melanogrammus aeglefinus). Can. J. Fish. Aquat. Sci. 49, 2527-2537. 